\title{
FACTORS AFFECTING SILICOMANGANESE PRODUCTION USING MANGANESE RICH SLAG IN THE CHARGE
}

\author{
M. Eissa, A. Fathy, A. Ahmed, A. El-Mohammady and K. El-Fawakhry \\ Steel and Ferroalloys Department, Central Metallurgical Research \& Development Institute, \\ PO Box 87 Helwan, 11421 Cairo, Egypt. E-mail: rucmrdi@rusys.eg.net
}

\begin{abstract}
Silicomanganese is widely used as a complex reducer and an alloying addition in the production of various grades of steel due to its economic and metallurgical advantages. It is also used as a semi-product in the manufacture of medium- and low-carbon ferromanganese and metallic manganese.
\end{abstract}

Manganese-rich slag, resulting from high carbon ferromanganese production, has the advantages of high manganese content, high $\mathrm{Mn} / \mathrm{Fe}$ ratio, low excess oxygen, low phosphorus content, low fine content and low cost. Such slag seems to be very attractive to use as raw materials for the production of silicomanganese alloys.

In the present study, experimental heats were designed and carried out to optimise the factors affecting the production process of silicomanganese using manganese rich slag in the charge.

The results of pilot plant experimental heats showed that the optimum metallic yield and recoveries of manganese and silicon are obtained with initial slag basicity, $(\mathrm{CaO}+\mathrm{MgO}) /\left(\mathrm{Al}_{2} \mathrm{O}_{3}\right)$, equals 1.8 by using dolomite as fluxing material and charging quartzite and fluorspar in percentage of $25 \%$ and $4 \%$ of the blend, respectively. The results showed also that an amount of $30 \%$ of coke in excess of the stoichiometric amount should be added. These result are relative for the specific high $\mathrm{Al}_{2} \mathrm{O}_{3}$ ores used.

\section{INTRODUCTION}

In Egypt, manganese rich slag is produced from the high carbon ferromanganese production process. This slag has average $38 \% \mathrm{Mn}$. In addition to its high manganese content, it has also the advantages of high $\mathrm{Mn} / \mathrm{Fe}$ ratio, low excess oxygen, low phosphorus content, low fine content and low cost. The possibility of using such slag for the production of silicomanganese alloys seems to be very attractive and has strong economical impact on the production process.

Trials were made by many authors [1-3] in which high manganese slag, manganese ore and quartz were smelted using a graphite lined ferroalloy furnace with coke as the reductant to obtain ferrosilicomanganese alloys. During this process the recovery of the manganese and silicon was found to be affected by temperatures, slag basicity, slag viscosity and the amount of reductant.

The process for silicomanganese needs a higher temperature compared to the smelting of ferromanganese. The higher temperature is needed for successful reduction of silicon. It is noticeable that alumina has a

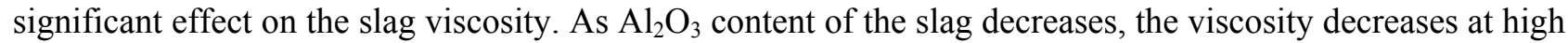
temperature.

On the other hand, the main factor affecting the manganese recovery is manganous oxide activity in the molten slag, which is determined by the slag composition. Basic oxides play an important role in improving slag behaviors. The oxides $\mathrm{CaO}$ and $\mathrm{MgO}$ increase the activity of the $\mathrm{MnO}$ but decrease the activity of $\mathrm{SiO}_{2}$, which is necessary to produce silicomanganese [4]. The term of basicity is defined to evaluate slag function and properties. 
The definitions of the slag basicity depending on the practices and amounts of the constituents, are as following:

$$
\begin{aligned}
& \text { Binary basicity } \mathrm{B}_{1}=(\mathrm{CaO}) /\left(\mathrm{SiO}_{2}\right) \\
& \text { Ternary basicity } \mathrm{B}_{2}=(\mathrm{CaO}+\mathrm{MgO}) /\left(\mathrm{SiO}_{2}\right)
\end{aligned}
$$

Many authors [5-7] studies the effect of the basicity $\left(B_{1}\right.$ or $\left.B_{2}\right)$ and they gave different preferable range for the SiMn production: 0.33-0.48 [5] and 0.60-0.75 [6] for $B_{1}$ and 0.65-0.9 [7] for $B_{2}$.

For correct assessment of slag basicity when smelting high silicon alloys, the magnitude of slag basicity is taken from the ratio $\mathrm{B}_{3}=(\mathrm{CaO}+\mathrm{MgO}) /\left(\mathrm{Al}_{2} \mathrm{O}_{3}\right)$ instead of the $\mathrm{B}_{1}$ or $\mathrm{B}_{2}$ because the $\mathrm{B}_{3}$ is more affecting the recovery of manganese and silicon than the $B_{1}$ or $B_{2}$, due to $\mathrm{SiO}_{2}$ reduction in smelting process [4]. Nikolaev [4] found that an optimum $B_{3}$ at 2.5, while Emlin et al. [6] concluded an optimum $B_{3}$ at the range 1.2-2.2.

This study aims at investigating the different parameters controlling the production of silicomanganese alloy when using manganese rich slag in the blend.

\section{EXPERIMENTAL}

To investigate the effect of slag basicity and amount of reductant, fluorspar and quartzite on metallic yield, manganese and silicon recoveries, series of 29 pilot plant heats were carried out. Dolomite, limestone and fluorspar were used separately or in mixtures as a fluxing material. Slag basicity of charge $(\mathrm{CaO}+\mathrm{MgO}) /$ $\left(\mathrm{Al}_{2} \mathrm{O}_{3}\right)$ varied in the range of $1-2.5$.

\begin{tabular}{|c|c|c|c|c|c|c|c|c|}
\hline 苞 & 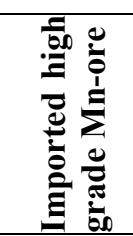 & 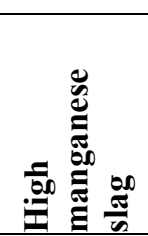 & 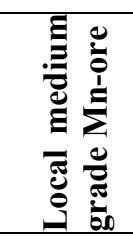 & 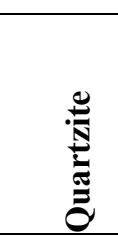 & 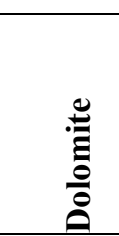 & 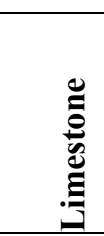 & $\frac{0}{0}$ & 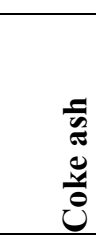 \\
\hline $\mathrm{Mn}$ & 48.15 & 38.41 & 39.0 & - & - & - & - & 2.43 \\
\hline $\mathrm{MnO}_{2}$ & 68.09 & - & 61.62 & - & - & - & - & - \\
\hline $\mathrm{MnO}$ & 6.22 & 49.584 & - & - & - & - & - & - \\
\hline $\mathrm{Fe}_{2} \mathrm{O}_{3}$ & 3.61 & - & 28.3 & 0.2 & 0.86 & & & 27.88 \\
\hline $\mathrm{FeO}$ & - & 4.05 & - & - & - & - & - & - \\
\hline $\mathrm{Fe}$ & 2.53 & 3.14 & 19.8 & 0.14 & - & 0.33 & - & - \\
\hline $\mathrm{SiO}_{2}$ & 12.56 & 19.39 & 3.5 & 95 & 6.37 & 3.86 & - & 42.2 \\
\hline $\mathrm{CaO}$ & 0.17 & 11.68 & 0.90 & 0.3 & 29.35 & 51.53 & - & 4.1 \\
\hline $\mathrm{MgO}$ & 0.13 & 1.9 & 0.30 & 0.3 & 17.71 & 0.59 & - & 3.2 \\
\hline $\mathrm{Al}_{2} \mathrm{O}_{3}$ & 2.71 & 9.66 & 1.0 & 2.5 & 0.99 & 0.79 & - & 28.4 \\
\hline $\mathrm{P}_{2} \mathrm{O}_{5}$ & - & 0.1 & 0.14 & - & - & - & - & 0.252 \\
\hline $\mathrm{P}$ & 0.096 & 0.04 & - & - & - & - & - & 0.11 \\
\hline$S$ & 0.009 & 0.34 & 0.3 & - & - & - & - & 0.75 \\
\hline $\mathrm{Na}_{2} \mathrm{O}$ & 0.14 & 0.65 & 0.3 & - & 0.18 & 1.63 & - & - \\
\hline $\mathrm{K}_{2} \mathrm{O}$ & 0.54 & 1.86 & 0.1 & - & 1.38 & 0.34 & - & - \\
\hline $\mathrm{TiO}_{2}$ & - & - & - & - & - & - & - & 1.2 \\
\hline L.O.I. at $1000(\mathrm{C}$ & - & - & - & - & 43.48 & 41.1 & - & - \\
\hline $\mathrm{H} 2 \mathrm{O}$ & 0.71 & - & 2.0 & - & 0.23 & 0.48 & - & - \\
\hline Moisture & 3.5 & - & 0.8 & - & 0.48 & 0.6 & 1.8 & - \\
\hline Ash & - & - & - & - & - & - & 13.5 & - \\
\hline Fixed carbon & - & - & - & - & - & - & 83.3 & - \\
\hline V.M. & - & - & - & - & - & - & 1.4 & - \\
\hline
\end{tabular}

Table 1. Chemical composition of raw materials used in the production of ferrosilicomanganese, wt. \%. 


\subsection{Raw Materials}

The chemical analysis of raw materials, reducing agent and additives used in the production of ferrosilicomanganese is given in Table 1.

\subsection{Equipment}

\subsubsection{Submerged electric arc furnace}

Smelting of silicomanganese was carried out in a $100 \mathrm{kVA}$ pilot scale submerged electric arc-furnace. The power is supplied to the furnace by AC stepwise transformer with a primary electric power of 380 Volts and 220 Amperes capable of providing secondary current of 2000 Amperes at 40 Volts through two $75 \mathrm{~mm}$ diameter non-tilting graphite electrodes. SiMn was smelted at $1600 \mathrm{~A}$ and $63 \mathrm{~V}$. The inside dimensions of the overall furnace were $56 \mathrm{~cm}$ across the longer axis and $38 \mathrm{~cm}$ in depth. The furnace wall and bottom were rammed with thick magnesite layer and another layer of graphite. The normal capacity of the furnace is 150 $\mathrm{kg}$. The furnace roof is furnitured with water-cooled roof.

\subsubsection{The built up shaft}

A built up shaft was used for casting of silicomanganese. The shell of the shaft was manufactured from a cylindrical steel pipe with $8-10 \mathrm{~mm}$ wall thickness. The bottom of the shaft was closed by means of detachable steel plate. Both the bottom and the walls of the shaft were lined by ramming magnesite layer and another layer of graphite.

\subsubsection{Smelting technique}

The preheated furnace was started on using a graphite strip placed between the two electrodes. Then small amounts of the charge were charged into the furnace until melting. Other portions of the charge were added in interval up to the complete smelting of the charge. The weight of blend used in each run was $60 \mathrm{~kg}$.

Table 2. Effect of slag composition on silicomanganese production.

\begin{tabular}{|c|c|c|c|c|c|c|c|c|c|c|c|c|c|c|c|c|c|}
\hline \multirow[b]{2}{*}{ 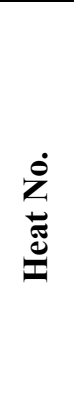 } & \multicolumn{4}{|c|}{ Blend Weight, $\mathrm{kg}$} & \multirow[b]{2}{*}{ 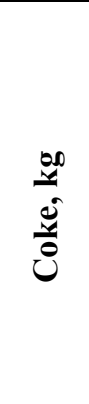 } & \multicolumn{2}{|c|}{ Fluxes, kg } & \multirow[b]{2}{*}{ 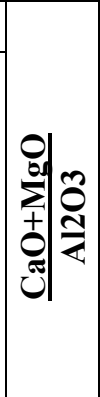 } & \multirow[b]{2}{*}{ 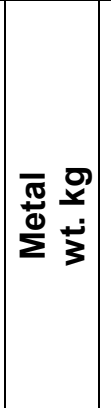 } & \multirow[b]{2}{*}{$\begin{array}{l}\frac{8}{2} \\
\dot{3} \\
\frac{\pi}{3} \\
\frac{\pi}{\omega}\end{array}$} & \multirow[b]{2}{*}{ 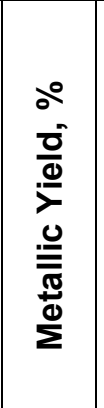 } & \multirow[b]{2}{*}{ 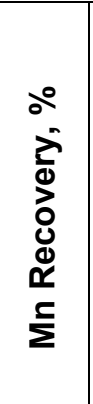 } & \multirow[b]{2}{*}{ 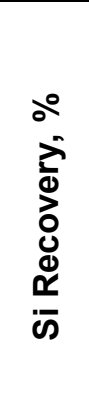 } & \multicolumn{4}{|c|}{ Metal Analysis, wt. \% } \\
\hline & $\frac{8}{0}$ & 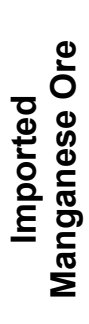 & 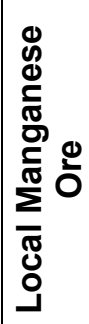 & $\begin{array}{l}\frac{D}{\frac{N}{N}} \\
\frac{t}{\pi} \\
\frac{0}{3} \\
0\end{array}$ & & 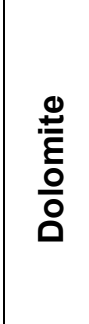 & 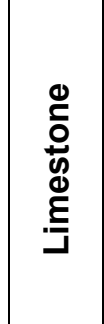 & & & & & & & 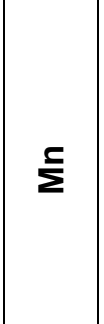 & க & 0 & 迎 \\
\hline 1 & 30 & 12 & 6 & 12 & 13.5 & - & - & 1.034 & 13.3 & 30 & 40.24 & 41.32 & 13.03 & 69.4 & 10.5 & 1.2 & 17.3 \\
\hline 2 & 30 & 12 & 6 & 12 & 13.5 & 3.30 & - & 1.5 & 15.25 & 30 & 46.14 & 47.9 & 18.22 & 70.1 & 12.8 & 1.8 & 14.06 \\
\hline 3 & 30 & 12 & 6 & 12 & 13.5 & 5.62 & - & 1.6 & 17.5 & 30 & 52.95 & 57.3 & 22.3 & 73.15 & 13.66 & 1.55 & 10.88 \\
\hline 4 & 30 & 12 & 6 & 12 & 13.5 & 7.5 & - & 1.8 & 19.0 & 30 & 57.5 & 61.5 & 25.47 & 72.34 & 14.36 & 1.45 & 11.4 \\
\hline 5 & 30 & 12 & 6 & 12 & 13.5 & 9.25 & - & 2.0 & 18.0 & 30 & 54.46 & 57.54 & 20.99 & 71.41 & 12.85 & 1.70 & 13.15 \\
\hline 6 & 30 & 12 & 6 & 12 & 13.5 & 11.9 & - & 2.5 & 16.5 & 37 & 46.90 & \begin{tabular}{|l|l} 
\\
\end{tabular} & 20.67 & 71.77 & 14.29 & 1.96 & 11.42 \\
\hline 7 & 30 & 12 & 6 & 12 & 13.5 & - & 3.2 & 1.5 & 11 & 32 & 40.24 & 41.32 & 13.03 & 73.00 & 10.01 & 1.5 & 13.5 \\
\hline 8 & 30 & 12 & 6 & 12 & 13.5 & - & 5.5 & 1.6 & 13 & 34 & 39.3 & 40.81 & 15.7 & 70.12 & 12.93 & 1.8 & 14.66 \\
\hline 9 & 30 & 12 & 6 & 12 & 13.5 & - & 7.0 & 1.8 & 15.5 & 38 & 46.9 & 50.82 & 16.96 & 73.24 & 11.72 & 1.95 & 12.74 \\
\hline 10 & 30 & 12 & 6 & 12 & 13.5 & - & 9.2 & 2.0 & 14 & 36 & 42.3 & 44.05 & 16.85 & 70.28 & 12.9 & 2.1 & 13.4 \\
\hline 11 & 30 & 12 & 6 & 12 & 13.5 & - & 11.5 & 2.5 & 12 & 30 & 36.31 & 38.46 & 16.4 & 71.6 & $\mid 14.7$ & 2.3 & 10.72 \\
\hline 12 & 30 & 12 & 6 & 12 & 13.5 & 1.750 & 1.6 & 1.5 & 13 & 30 & 39.3 & 40.33 & 18.72 & 69.3 & 15.43 & 2.1 & \begin{tabular}{|l|l}
17.0 \\
\end{tabular} \\
\hline 13 & 30 & 12 & 6 & 12 & 13.5 & 2.750 & 2.850 & 1.6 & 15 & 35 & 45.38 & 43.2 & 22.96 & 64.3 & 16.4 & 1.9 & \begin{tabular}{|l|}
17.2 \\
\end{tabular} \\
\hline 14 & 30 & 12 & 6 & 12 & 13.5 & 3.5 & 3.75 & 1.8 & 18.5 & 50 & 56.9 & \begin{tabular}{|l|l|}
54.66 \\
\end{tabular} & 25.73 & 66 & 14.9 & 2.3 & 16.4 \\
\hline 15 & 30 & 12 & 6 & 12 & 13.5 & 4.6 & 4.75 & 2.0 & 16.3 & 32.5 & 49.32 & 49.62 & 21.30 & 68.0 & 14.2 & 2.6 & 15.0 \\
\hline 16 & 30 & 12 & 6 & 12 & 13.5 & 5.75 & 5.95 & 2.5 & 15.5 & 30 & 46.9 & 48.8 & 17.8 & 70.3 & 12.3 & 3.4 & 12.5 \\
\hline
\end{tabular}




\section{RESULTS AND DISCUSSION}

The most important factor in silicomanganese production is the composition of the slag. In this work, the slag basicity $(\mathrm{CaO}+\mathrm{MgO}) /(\mathrm{Al} 2 \mathrm{O} 3)$ was adjusted by using different fluxes (dolomite, limestone and dolomite-limestone together in equals weights). Table 2 summarizes the input, output and chemical composition of the produced metal.

\subsection{Effect of slag basicity}

Figures (1-3) represent the effect of slag basicities using dolomite, limestone and dolomite-limestone together, respectively, for adjusting the $(\mathrm{CaO}+\mathrm{MgO}) /\left(\mathrm{Al}_{2} \mathrm{O}_{3}\right)$ ratio, on the metallic yield, manganese and silicon recoveries.

It can be deduced from these figures that there is an optimum value at $(\mathrm{CaO}+\mathrm{MgO}) /\left(\mathrm{Al}_{2} \mathrm{O}_{3}\right)=1.8$, for metallic yield and recoveries of manganese and silicon.

The theoretically calculated composition of the slag without addition of dolomite, limestone, dolomite-

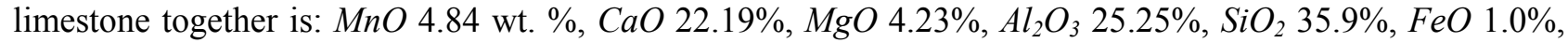
$\mathrm{K}_{2} \mathrm{O}_{3} 3.85 \%, \mathrm{Na}_{2} \mathrm{O} 1.38 \%$. The $\mathrm{Al}_{2} \mathrm{O}_{3}$ content in the slag is clearly high $(25.55 \%)$. The refractory alumina oxide with high percent in the slag will impair simultaneous reduction of manganese and silicon oxides with carbon. To compensate this effect of $\mathrm{Al}_{2} \mathrm{O}_{3}$, it is necessary to introduce $\mathrm{MgO}$ and/or $\mathrm{CaO}$. Therefore, increasing of dolomite and/or limestone quantity in charge will decrease $\mathrm{Al}_{2} \mathrm{O}_{3}$ percent gradually in the slag and consequently decrease slag viscosity. So, the slag metal reactions enhance and metallic yield, recoveries of manganese and silicon steadily increase up to $(\mathrm{CaO}+\mathrm{MgO}) /\left(\mathrm{Al}_{2} \mathrm{O}_{3}\right)=1.8$. Further increase in the basicity is accompanied by a general decrease in yield and recoveries. This could be attributed to formation of viscous magnesium and calcium silicates and also difficult reducible series of $\mathrm{CaO} . \mathrm{MnO}$, which decrease the activities of manganese and silicon oxides and impair the recoveries of $\mathrm{Mn}$ and $\mathrm{Si}$.

\subsection{Effect of quartzite}

The effect of quartzite amount on the metallic yield and recoveries of manganese and silicon are indicated in Table 3 and Figure 4.

Table 3. Effect of quartzite on silicomanganese production.

\begin{tabular}{|c|c|c|c|c|c|c|c|c|c|c|c|c|c|c|c|c|c|}
\hline \multirow[b]{2}{*}{ 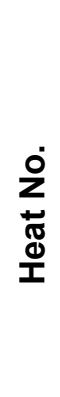 } & \multicolumn{4}{|c|}{ Blend Weight, kg } & \multirow[b]{2}{*}{ 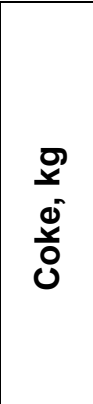 } & \multicolumn{2}{|c|}{ Fluxes, kg } & \multirow[b]{2}{*}{ 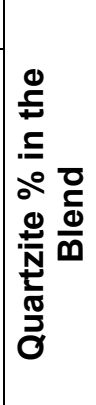 } & \multirow[b]{2}{*}{ 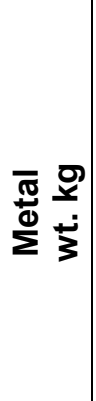 } & \multirow[b]{2}{*}{$\begin{array}{l}\frac{0}{3} \\
\dot{3} \\
\dot{3} \\
\frac{\pi}{\omega}\end{array}$} & \multirow[b]{2}{*}{ 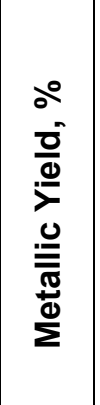 } & \multirow[b]{2}{*}{ 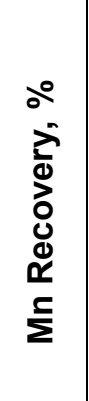 } & \multirow[b]{2}{*}{ 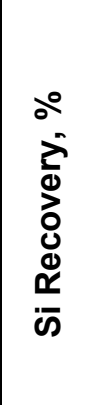 } & \multicolumn{4}{|c|}{ Metal Analysis, wt. \% } \\
\hline & $\frac{8}{\infty}$ & 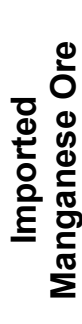 & 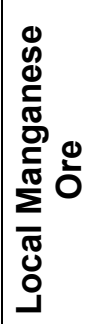 & $\begin{array}{l}\frac{0}{N} \\
\frac{N}{\pi} \\
\frac{\pi}{3}\end{array}$ & & 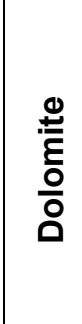 & $\begin{array}{l}\frac{\bar{\sigma}}{0} \\
\frac{0}{0} \\
\frac{0}{2} \\
\frac{\bar{z}}{4}\end{array}$ & & & & & & & $\sum$ & க் & 0 & $\stackrel{0}{\Perp}$ \\
\hline 17 & 30 & 12 & 6 & 5.3 & 13.5 & 7.5 & 2 & 10 & 11.5 & 18 & 33.3 & 36.45 & 11.06 & 70.8 & 10.3 & 2.1 & 16.1 \\
\hline 18 & 30 & 12 & 6 & 8.4 & 13.5 & 7.5 & 2 & 15 & 15.0 & 45 & 45.38 & 49.1 & 15.96 & 73.1 & $\mid 11.4$ & 1.8 & 13.5 \\
\hline 19 & 30 & 12 & 6 & 16 & 13.5 & 7.5 & 2 & 25 & 20.0 & 54 & 60.5 & 65.8 & 25.2 & 73.5 & 13.5 & 1.85 & 11.0 \\
\hline 20 & 30 & 12 & 6 & 20.6 & 13.5 & 7.5 & 2 & 30 & 15.5 & 40 & 46.9 & 47.0 & 18.05 & 70.0 & 12.48 & 2.1 & 14.7 \\
\hline 21 & 30 & 12 & 6 & 12 & 13.5 & 7.5 & 2 & 20 & $\mid 17.0$ & 45 & 52.95 & 55.17 & 22.85 & 72.5 & $\mid 14.4$ & 1.1 & 11.8 \\
\hline
\end{tabular}

The metallic yield and recovery increase by increasing the quartzite percent in the charge to optimum $25 \%$. Further increase in the quartzite percent is accompanied by a general decrease in the metallic yield and manganese and silicon recoveries. 
As manganese and silicon are reduced mainly not from their free oxides, but from their oxides combined as silicates, the following reaction applies:

$$
\mathrm{MnO} \mathrm{SiO}_{2}+3 \mathrm{C} \rightarrow \mathrm{MnSi}+3 \mathrm{CO}
$$

Thus, the addition of quartzite to the charge gives more free $\mathrm{SiO}_{2}$ to combine with alumina to form alumina silicate and free $\mathrm{SiO}_{2}$ to be reduced. In this case, $\mathrm{CaO}$ and $\mathrm{MgO}$ existing in the slag raise the activity of the $\mathrm{MnO}$ owing to the course of the reaction:

$$
\mathrm{MnO} . S i O_{2}+(\mathrm{CaO}, \mathrm{MgO}) \rightarrow \mathrm{MnO}+(\mathrm{CaO}, \mathrm{MgO}) \mathrm{SiO}_{2}
$$

with the result of increasing of metallic yield and recovery of $\mathrm{Mn}$ and $\mathrm{Si}$. The depression of both metallic yield and recovery by further addition of quartzite could be attributed to presence of more $\mathrm{SiO}_{2}$ leading to formation of complex silicate, which increase slag viscosity and consequently impair the metallic yield and recovery.

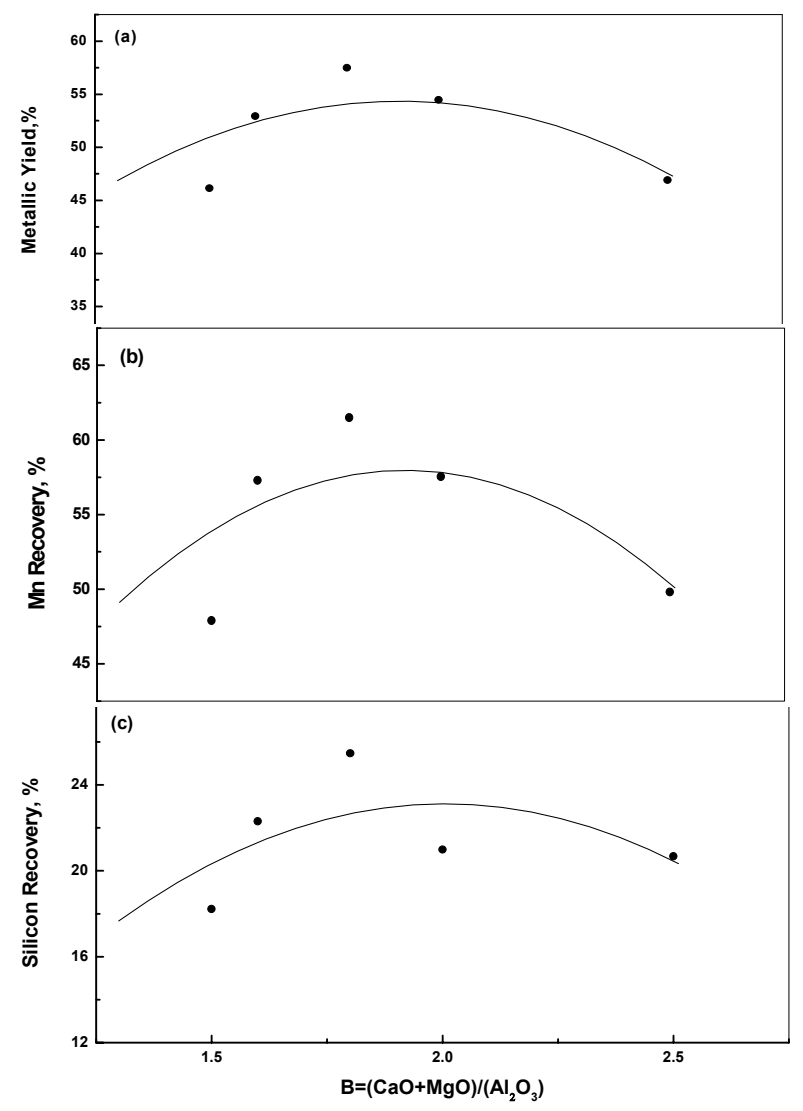

Figure 1. Effect of basicity, $(\mathrm{CaO}+\mathrm{MgO}) /\left(\mathrm{Al}_{2} \mathrm{O}_{3}\right)$, on (a) metallic yield, (b) manganese recovery and (c) silicon recovery, using dolomite as flux in the production of silicomanganese.

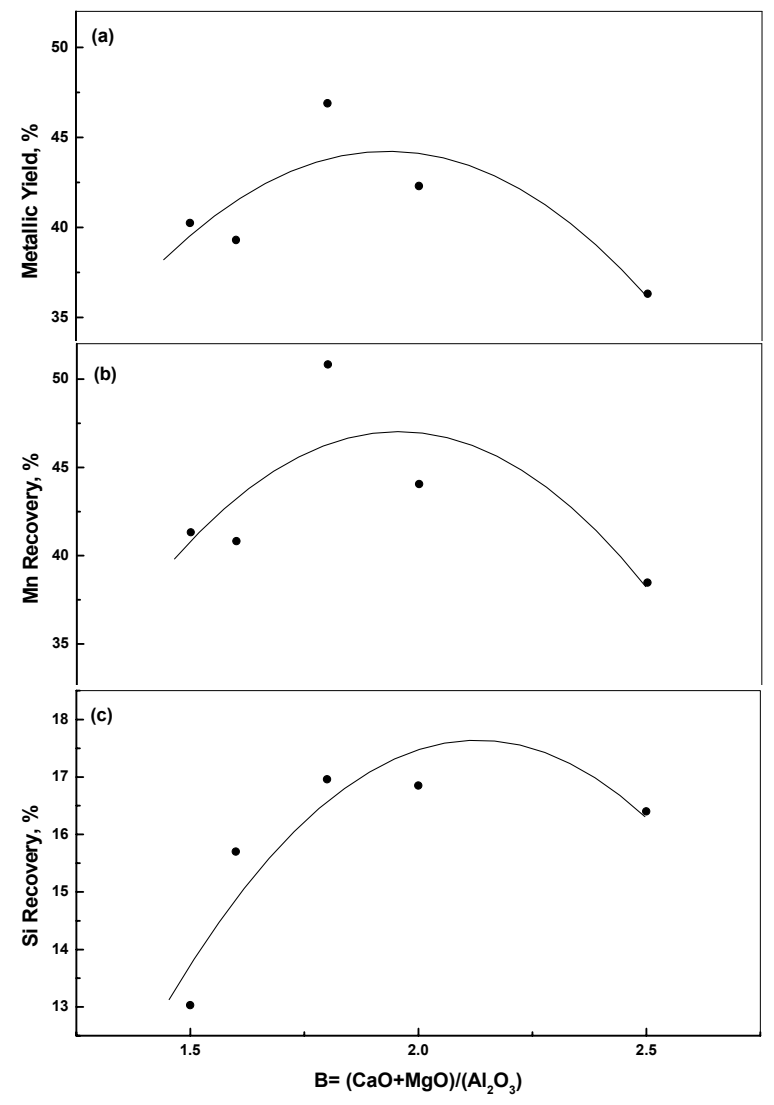

Figure 2. Effect of basicity, $(\mathrm{CaO}+\mathrm{MgO}) /\left(\mathrm{Al}_{2} \mathrm{O}_{3}\right)$, on (a) metallic yield, (b) manganese recovery and (c) silicon recovery, using limestone as fluxing material in the production of silicomanganese.

\subsection{Effect of fluorspar}

Table 4 and Figure 5 summarize the effect of fluorspar on the metallic yield and recovery of $\mathrm{Mn}$ and $\mathrm{Si}$. The metallic yield, and manganese and silicon recoveries increase by increasing the fluorspar content in the charge up to a certain percent of about $4 \%$ of the charge.

The slag of silicomanganese consists of refractory oxides $\mathrm{Al}_{2} \mathrm{O}_{3}, \mathrm{CaO}, \mathrm{MgO}$ and $\mathrm{SiO}_{2}$, i.e. viscous slag. The addition of fluorspar will increase the fluidity of the slag, i.e. facilitates flow down of metallic droplets. 
Addition of fluorspar up to $4 \%$ of the charge is accompanied by slight increase of metallic yield and recovery of $\mathrm{Mn}$ and $\mathrm{Si}$ due to volatile of silicon according to the following reaction:

$$
2 \mathrm{CaF}_{2}+\mathrm{SiO}_{2} \rightarrow 2 \mathrm{CaO}+\mathrm{SiF}_{4}(g)
$$

which in turn decrease the slag viscosity.

Further increase of fluorspar raises the $\mathrm{CaO}$ content in slag, which in turn raises the slag viscosity. The resultant of these two opposite effects leads to slight increase in metallic yield and recovery.

\subsection{Effect of reductant amount}

Table 5 summarizes the results of heats carried out to investigate the effect of coke amount on the production parameters of silicomanganese. The effect of coke added: coke calculated ratio (coke calculated is the theoretical coke needed for the reduction) on the metallic yield and recoveries of manganese and silicon is illustrated in Figure 6.

The maximum of both metallic yield and manganese recovery was obtained at coke add. : coke calculated ratio 1.3. The metallic yield and $M n$, Si recovery increase by increasing the amount of reductant in the charge. This may be explained by the increasing the oxidation rate of carbon in the open furnace.

The depression in the metallic yield and manganese recovery at high ratio $(>1.3)$ is due to the increased amount of coke ash resulting from increasing the coke weight in the charge. These ashes containing high percents of $\mathrm{SiO}_{2}$ and $\mathrm{Al}_{2} \mathrm{O}_{3}$, which increase the viscosity of the slag leading to decrease the manganese recovery and metallic yield.

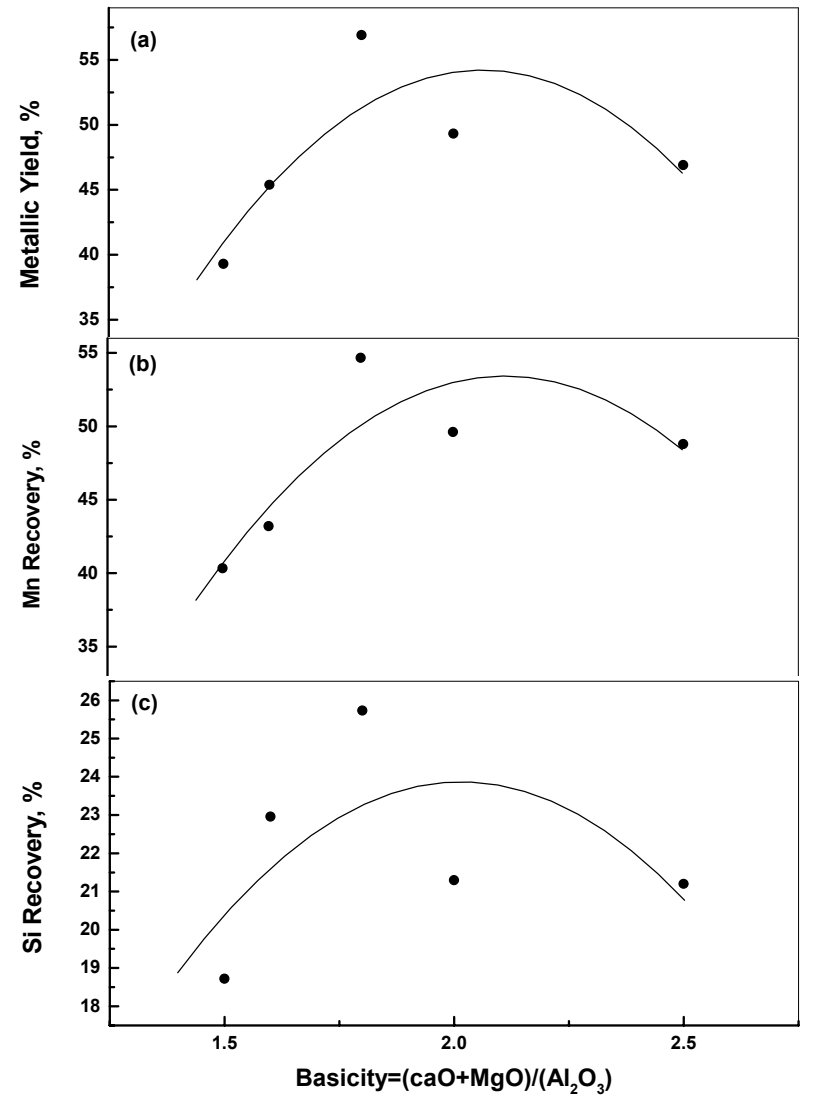

Figure 3. Effect of basicity, $(\mathrm{CaO}+\mathrm{MgO}) /\left(\mathrm{Al}_{2} \mathrm{O}_{3}\right)$, on (a) metallic yield, (b) manganese recovery and (c) silicon recovery, using dolomite and limestone as flux in the production of silicomanganese.

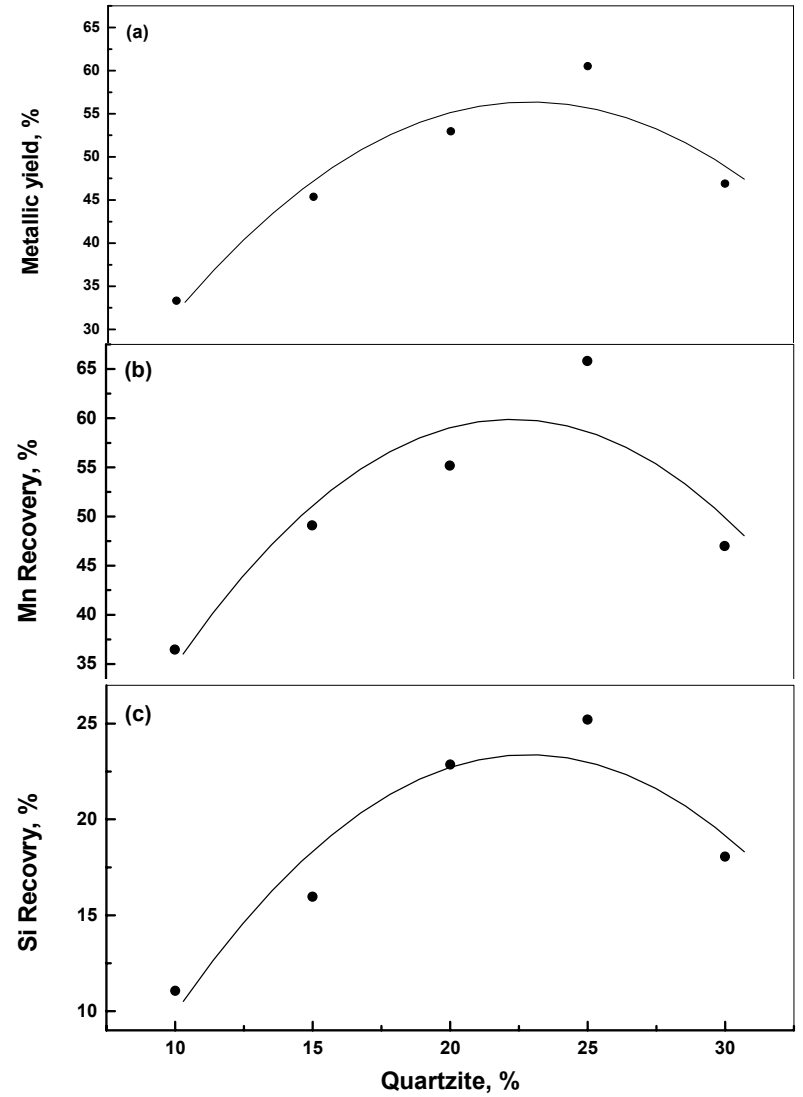

Figure 4. Effect of quartzite percent in the blend on (a) metallic yield, (b) manganese recovery and (c) silicon recovery, in the production of silicomanganese. 
Table 4. Effect of fluorspar on silicomanganese production.

\begin{tabular}{|c|c|c|c|c|c|c|c|c|c|c|c|c|c|c|c|c|c|}
\hline \multirow[b]{2}{*}{ 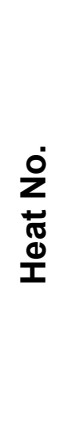 } & \multicolumn{4}{|c|}{ Blend Weight, kg } & \multirow[b]{2}{*}{ 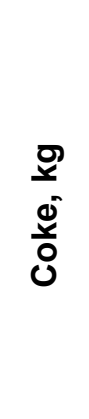 } & \multicolumn{2}{|c|}{ Fluxes, kg } & \multirow[b]{2}{*}{ 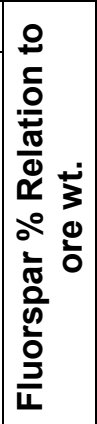 } & \multirow[b]{2}{*}{ 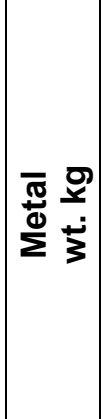 } & \multirow[b]{2}{*}{$\begin{array}{l}\stackrel{D}{8} \\
\dot{3} \\
\dot{3} \\
\bar{D} \\
\frac{\pi}{\omega}\end{array}$} & \multirow[b]{2}{*}{ 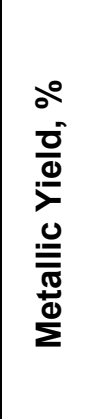 } & \multirow[b]{2}{*}{ 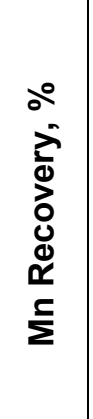 } & \multirow[b]{2}{*}{ 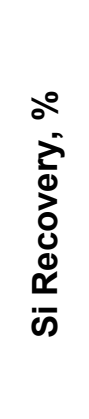 } & \multicolumn{4}{|c|}{ Metal Analysis, wt. \% } \\
\hline & $\frac{\text { D }}{\text { ஸ }}$ & 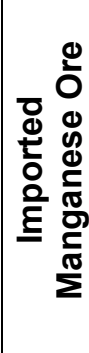 & 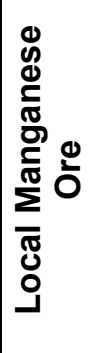 & 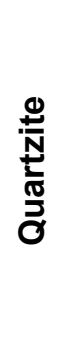 & & 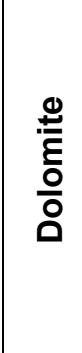 & $\begin{array}{l}\frac{2}{\pi} \\
\frac{0}{0} \\
\frac{0}{0} \\
\frac{0}{2} \\
\frac{2}{4}\end{array}$ & & & & & & & $\sum$ & க் & 0 & $\stackrel{0}{\leftarrow}$ \\
\hline 1 & 30 & 12 & 6 & 12 & 13.5 & 7.5 & - & - & 13.3 & 30 & 40.24 & 41.32 & 13.03 & 69.4 & 10.5 & 1.2 & 17.3 \\
\hline 22 & 30 & 12 & 6 & 12 & 13.5 & 7.5 & 1 & 2 & 16 & 46 & 48.41 & 50.3 & 22.2 & 70.2 & 14.0 & 1.5 & 12.5 \\
\hline 21 & 30 & 12 & 6 & 12 & 13.5 & 7.5 & 2 & 4 & 17.5 & 45 & 52.95 & 55.17 & 23.5 & 72.5 & 14.4 & 1.1 & 11.8 \\
\hline 24 & 30 & 12 & 6 & 12 & 13.5 & 7.5 & 3 & 6 & 18.0 & 36 & 54.5 & 56.4 & 26.1 & 70.0 & 15.56 & 1.05 & 12.75 \\
\hline 25 & 30 & 12 & 6 & 12 & 13.5 & 7.5 & 4 & 8 & 18.5 & 32.5 & 56.0 & 58.0 & 26.2 & 70.0 & 15.32 & 1.45 & 12.2 \\
\hline
\end{tabular}

Table 5. Effect of reductant on silicomanganese production.

\begin{tabular}{|c|c|c|c|c|c|c|c|c|c|c|c|c|c|c|c|c|c|}
\hline \multirow[b]{2}{*}{ 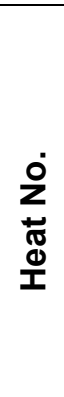 } & \multicolumn{4}{|c|}{ Blend Weight, kg } & \multirow[b]{2}{*}{$\begin{array}{l}\stackrel{0}{⿰} \\
\dot{0} \\
\dot{y} \\
\dot{0}\end{array}$} & \multicolumn{2}{|c|}{ Fluxes, $\mathbf{k g}$} & \multirow[b]{2}{*}{ 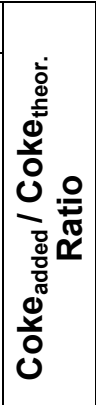 } & \multirow[b]{2}{*}{ 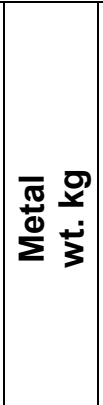 } & \multirow[b]{2}{*}{$\begin{array}{l}D \\
\dot{2} \\
\dot{3} \\
\dot{3} \\
\frac{\pi}{\omega}\end{array}$} & \multirow[b]{2}{*}{ 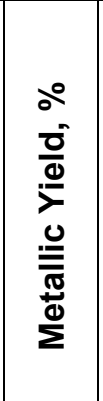 } & \multirow[b]{2}{*}{ 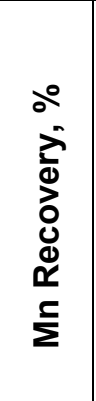 } & \multirow[b]{2}{*}{ 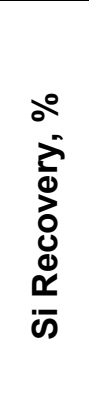 } & \multicolumn{4}{|c|}{ Metal Analysis, wt. \% } \\
\hline & $\frac{8}{\infty}$ & 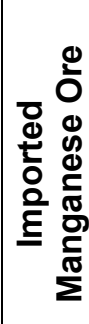 & 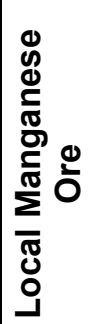 & 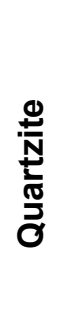 & & 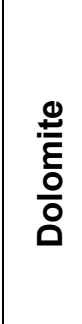 & $\begin{array}{l}\frac{\bar{\pi}}{0} \\
\frac{0}{0} \\
\frac{0}{0} \\
\frac{0}{2} \\
\frac{1}{4}\end{array}$ & & & & & & & $\underline{\Sigma}$ & कं & 0 & 迎 \\
\hline 26 & 30 & 12 & 6 & 12 & 11.5 & 7.5 & 2 & 0.85 & 15.0 & 30 & 45.38 & 49.15 & 19.6 & 73.2 & 14.0 & 1.05 & 10.2 \\
\hline 21 & 30 & 12 & 6 & 12 & 13.5 & 7.5 & 2 & 1.00 & 17.0 & 45.0 & 52.95 & 55.2 & 22.85 & 72.5 & 14.4 & 1.1 & 11.8 \\
\hline 27 & 30 & 12 & 6 & 12 & 15.5 & 7.5 & 2 & 1.15 & 19.0 & 52 & 59.9 & 62.2 & 24.8 & 73.2 & 14.0 & 1.2 & 10.27 \\
\hline 28 & 30 & 12 & 6 & 12 & 17.5 & 7.5 & 2 & 1.30 & 21.5 & 26 & 65.05 & 70.2 & 30.3 & 73.0 & 15.1 & 1.3 & 10.55 \\
\hline 29 & 30 & 12 & 6 & 12 & 19.5 & 7.5 & 2 & 1.45 & 18.0 & 30 & 54.9 & 54.1 & 31.0 & 67.1 & 18.42 & 1.4 & 12.1 \\
\hline
\end{tabular}




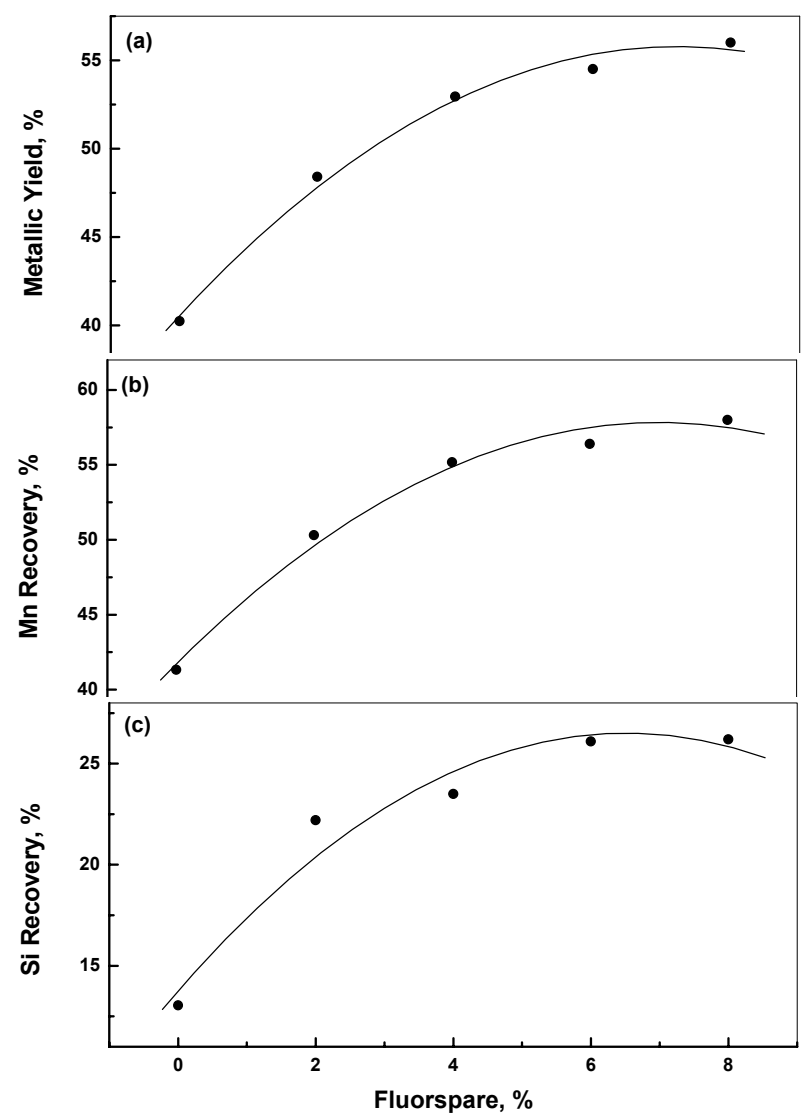

Figure 5. Effect of fluorspar percent in the blend on (a) metallic yield, (b) manganese recovery and (c) silicon recovery in the production of silicomanganese.

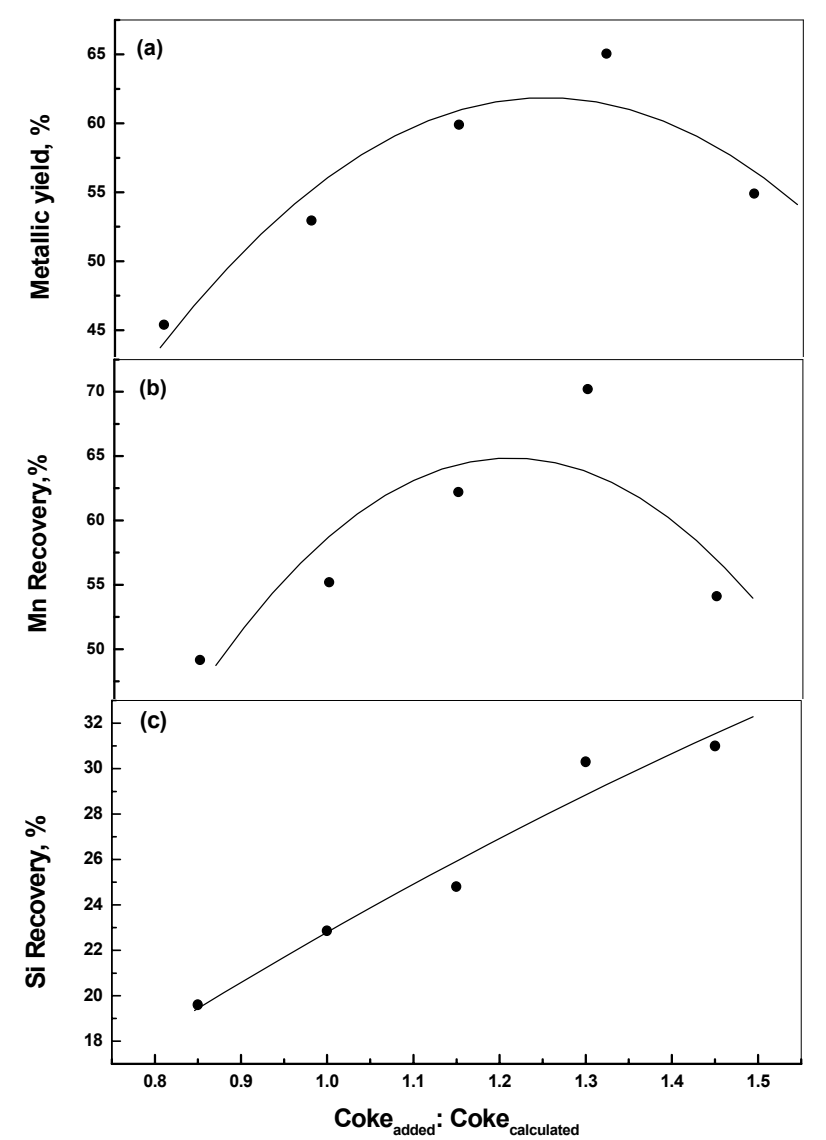

Figure 6. Effect of coke amount on (a) metallic yield, (b) manganese recovery and (c) silicon recovery, in the production of silicomanganese.

Silicon recovery steady increase by increasing the weight of coke in the charge. This steady increase can be attributed to the increase of the $\mathrm{SiO}_{2}$ in its simple oxide from resulting from the ash, which can be reduced by the fixed carbon of the coke with the result of increasing in the silicon recovery.

\section{CONCLUSIONS}

From the results of study the factors affecting the production process of silicomanganese using manganese rich slag in the charge, the following conclusions can be deduced:

- The highest metallic yield and recoveries of manganese and silicon are obtained with initial slag basicity, $(\mathrm{CaO}+\mathrm{MgO}) /\left(\mathrm{Al}_{2} \mathrm{O}_{3}\right)$ equals 1.8 by using dolomite as fluxing material.

- Adjusting the slag basicity by adding dolomite gives higher metallic yield, manganese and silicon recoveries comparing with that obtained by adding either limestone or dolomite and limestone together.

- The optimum amount of quartzite in the blend is $25 \%$. Further increase in the quartzite percent is accompanied by a general decrease in the metallic yield and manganese recoveries.

- The metallic yield and manganese and silicon recovery increase by increasing the fluorspar content in the charge up to a certain percent of about $4 \%$ of the charge. Further increase leads to slight increase in metallic yield and recoveries.

- The maximum of both metallic yield and manganese recovery is obtained at coke ${ }_{\text {add }}$ : coke calculated 1.3 . Above this ratio there is a depression in the metallic yield and manganese recovery. But silicon recovery steady increases by increasing the weight of coke in the charge.

- By adjusting the slag composition and fluxing addition, silicomanganese containing $73 \% \mathrm{Mn}, 15 \% \mathrm{Si}$ and $1.1 \% C$ has been successfully produced with metallic yield, manganese recovery and silicon recovery of $65 \%, 70 \%$ and $30 \%$, respectively. 


\section{ACKNOWLEDGEMENT}

The authors wish to acknowledge Professor Dr. M.L. Mishreky, Dr. H.S. El-Faramawy and Dr. T. Mattar, Steel and Ferroalloys Department, CMRDI for their helpful discussions throughout the course of this work.

\section{REFERENCES}

[1] Davis, E.G, Brantly, F.E and Wright, E.C., Recovery of manganese from slag formed by selective oxidation of high-manganese pig iron. Bur. Mines REP invest., 6728, 16P.U.S. Dept. of the Interior, Bureau of mines, Washinton, D.C, 1966. p. 1-15

[2] Edneral, F.P. Electrometallurgy of steel and ferroalloys. Mir publisher, Moscow, 1979, Vol. 2,pp.215.

[3] Eissa,M., El-Faramawy,H. and Farid,G. Production of high carbon ferromanganese using manganese rich slag in the charge. steel research, 1998. Vol. 69, No.9, p. 373-380.

[4] Nikolaev, V.I., Selection of optimum slag basicity in ferromanganese production. Steel in USSR, 1974, No. 4, p. 299-302.

[5] Gobdullin, T.G. Tolymbekov, M.Zh., Takenov, T.D., Baisanov, S., Buketov, E.A., and Druinskii, M.I., Smelting of silicomanganese. Otkrytiya, Izobret, Prom. Obraztsy, Tovarnye. Znaki, 1982. 8, p.109.

[6] Emlin, B.I., Pogrebnyak,A.I. Vodin, I.I. Matyashenko, N.K. Belan, V.D. Sarankin, V.A. Chupakhin, Yu.m. Shaposhnik, I.I. Shchedrovitskii, V.Ya. Silicomanganese smelting., Otkrytiya Izobret, 1986. 30, p.86.

[7] Chaichenko, A.A. Kashakashvili, G.V. Arabuli, I.A. Akhabadze, T.V. Tskitashvili, Yu.A. Veretennikov, O.K. Murakhovskii, V.V. and Sedov,A.A. Smelting of silicomanganese. Otkrytiya, Izobret, 1986, 44, 82. 